\title{
A study of Australian and Chinese accountants' attitudes towards independence issues and the impact on ethical judgments
}

\author{
Ying Han Fan $(\mathrm{PhD})^{*}$ \\ Lecturer \\ School of Accounting \\ Curtin University \\ Y.Fan@curtin.edu.au \\ Gordon Woodbine $(\mathrm{PhD})$ \\ Senior Lecturer \\ School of Accounting \\ Curtin University \\ Gordon.Woodbine@cbs.curtin.edu.au \\ Wei Cheng \\ Graduate Student \\ School of Accounting \\ Curtin University \\ eamoncheng@gmail.com
}

\section{*Correspondence Details}

Dr. Ying Han Fan

School of Accounting

Curtin University of Technology

GPO Box U1987

Perth, Western Australia

Phone: 61892662857

Fax: $\quad 61892667196$

Email: y.fan@curtin.edu.au 


\title{
A study of Australian and Chinese accountants' attitudes towards independence issues and the impact on ethical judgments
}

\begin{abstract}
:
Purpose - The purpose of this paper is to further extend research (Fan et al., 2012a) examining the attitudes of Chinese certified public accountants with respect to independence aspects of their professional codes of conduct and their influence on ethical judgment. These attitudes are compared with those of Australian public accountants Particular attention is given to refining a pre-existing instrument to determine measurement invariance.
\end{abstract}

Design/methodology/approach - A field survey of 81 Australian and 516 Chinese public accountants was conducted including the distribution of a questionnaire. Statistical analysis included confirmatory factor analysis and measurement invariance.

Findings - An analysis of data established the existence of a stable model for identifying the dimensions of independence of mind and independence in appearance within the context of the codes of conduct relevant to both cultures. Chinese accountants demonstrated significantly less concern about audit-client relationships affecting independence in appearance compared to their Australian counterparts. Interestingly, independence of mind was found to positively influence ethical judgment for both groups taken together, although Chinese accountants were the significant contributors to this model outcome.

Research limitations/implications - The relatively small sample of Australian accountants drawn from a limited population base could influence the quality of data analysis. This paper provides a further research direction for re-examining the relationship between Australian public accountants' attitudes toward their code of professional ethics and their ethical judgments in a significantly larger sample.

Practical implications - This paper is particularly useful to the profession in that it will provide members with better insights into how accountants in different cultural settings view audit independence issues and their relationships with audit clients. Second, this study offers a scale for measuring attitudes towards codes of professional ethics for further cross-cultural studies.

Original/value - An exploratory research exercise that indicates that accounting practitioners in divergent cultures demonstrate similar concerns about independence issues, although it is believed that guanxi is likely to explain why Chinese accountants are less concerned with independence of appearance issues. The research also presents a validated instrument for examining attitudes towards codes of ethics.

Keywords - Code of ethics, independence issues, ethical judgment, Australia, China

Paper type - Research paper 


\section{Introduction}

The auditing process involves much decision-making and substantial input by way of ethical judgments and intentions. Public accountants' professional ethics and the quality of their decision making are often questioned by critics who suggest that auditors in particular have the economic incentive to accommodate the needs of clients who steer them away from integrity and objectivity; resulting in undesirable conduct (Plugrath et al., 2007; Bazerman et al., 1997; Sikka, 2009; Cezair, 2010). In order to improve public confidence, national jurisdictions have established codes of professional conduct based on the International Federation of Accountants' (IFAC) Standard - Code of Ethics for Professional Accountants. Australia and China are two such countries. The Australian Accounting Professional and Ethical Standards Boards issued APES110 Code of Ethics for Professional Accountants in 2006, while the Chinese Institute of Certified Public Accountants (CICPA) issued CICPA Code of Ethics for Professional Accountants in 2009.

Fan et al. (2012a) developed a test instrument using a two dimensional scale based on two important aspects, i.e., independence of mind and independence in appearance, to examine Chinese auditors' attitudes toward these issues. Results suggest that Chinese auditors hold strong views about audit independence and also maintain they should avoid close audit-client relationships. In Australia, Pflugrath et al. (2007) found that Australian accounting professionals pay greater attention to the code of ethics when forming judgments on ethical issues. However, the issue as to whether Chinese public accountants view the above mentioned issues in the same way as their western counterparts has yet to be explored.

The major purpose of codes of conduct is to improve public accountants' performance and audit quality by strengthening their understanding the moral elements of the environments 
with which they interface (Pflugrath et al., 2007) because they regularly confront ethical dilemmas while carrying out their professional responsibilities (Herron and Gilbertson, 2004). Specifically, codes provide guidelines and professional norms of practice (e.g., principles in virtue, threats to independence etc.) to help accountants identify, evaluate, and resolve doubts implied in the moral hazards they regularly face (Herron and Gilbertson, 2004). According to the Hunt and Vitell (1986) general theory of business ethics, deontological norms such as those enshrined within codes of ethics could influence the ethical decision-making process. Researchers have presented evidence to justify the application of codes of ethics however most studies examine them within an organizational or business context. Only limited research (e.g., Pflugrath et al., 2007; Herron and Gilbertson, 2004) has examined codes of ethics within the accounting profession although Jones et al. (2003) suggested the role of codes of ethics in auditors' ethical decision making deserves further attention.

And also the question about whether a published code of ethics has any impact on accounting professionals' ethical judgments has produced a mixed response (Pflugrath et al., 2007). For example, Herron and Gilbertson (2004) found that the AICPA principles-based ethical codes do not effectively promote American accounting students' independence judgments especially where they apply lower levels of moral development. Pflugrath et al. (2007) showed that the presence of a code of professional ethics leads to better quality judgments by Australian accounting professionals but not future accountants (students). Modarres and Rafiee (2011) indicated that familiarity with the codes of ethics leads professional accountants to appreciate their intent and encourage higher levels of ethical judgment making. Thus the issue about whether important aspects relating to existing codes really help public accountants achieve and 
maintain proper attitudes and act independently when making decisions is worth further attention.

In order to explore the above issues, the authors attempt to address the following questions within a cultural context:

1. How do Australian and Chinese public accountants view important independence issues in their respective codes of professional ethics?

2. How do their views about the code of professional ethics affect their ethical judgments?

\section{Literature review and hypotheses development}

\section{Code of professional ethics in Australia}

A fundamental premise of a professional code is independence, which includes independence of mind and independence in appearance. Independence of mind requires accountants to recognise that their professional judgments must not be affected by any influences that could make them lose objectivity and hence independence. This implies that auditors in particular act with integrity, exercise impartiality and professional skepticism, and to resist client pressures in order to maintain independence. Independence in appearance represents third party perceptions on auditors' objectivity and may be unaffected by a financial interest in the assured client. 
Australian Accounting Professional and Ethical Standards Boards (APESB) adopted the concepts of independence of mind and independence in appearance and issued APES110 Code of Ethics for Professional Accountants in 2006 and subsequently amended it in February 2008. CPA Australia, the Institute of Chartered Accountants in Australia, and the Institute of Public Accountants are all members of the APESB (http://www.apesb.org.au/). The members of those accounting professional bodies must comply with APES 110 (APEX 110, 1.2 and 1.3).

The APES 110 is materially consistent with the IFAC Code of Ethics for Professional Accountants issued by the International Ethics Standards Board for Accountants (IESBA), therefore, providing international credibility. It emphasizes that the objectives of the accounting profession is to work to the "highest standards of professionalism" and to "attain the highest level of performance", and generally to meet the public interest requirement (Modarres and Rafiee, 2011, p.138). According to APES 110, a professional accountant's responsibility is more than satisfying the needs of an individual client or employer, it also requires that professionals act in the public interest.

APES 110 is divided into three parts, namely Part A: General Application of the Code, Part B: Members in Public Practice, and Part C: Members in Business. Part A firstly establishes the fundamental principles of professional ethics for public accountants which they have to comply with. The fundamental principles in the code include: (a) Integrity (Section 110), (b) Objectivity (Section 120), (c) Professional Competence and Due Care (Section 130), (d) Confidentiality (Section 140), (e) Professional Behaviour (Section 150). Secondly, the Code provides a conceptual framework to help accountants applying the fundamental principles to deal with the threats which often encountered by accounting professional during their professional service such as self-interest, self-review, advocacy, familiarity threats and intimidation. Then the 
Code illustrates how the conceptual framework could be applied when dealing with ethical conflict resolution issues. Therefore, public accountants can consult the conceptual framework and implied fundamental principles to identify and resolve threats to their professional conduct.

\section{Code of professional ethics in China}

The Chinese version of a code of professional ethics, titled the General Standard on Professional Ethics (GSPE) was originally issued in 1993 by the CICPA in accordance with the Law of the People's Republic of China on Certified Public Accountants (1993). It requires all members to observe the principles of independence, objectivity and fair dealing in performing professional activities (Article 4), maintain independence of mind and in appearance (Article 5), avoid any influence from others, or by any circumstances and personal feelings on their professional judgment (Article 9), and must not engage in any activities which could impair audit independence (Articles 7 and 8).

The Practice Guidelines on General Standards of Professional Ethics was issued in 2003 after Chinese accounting regulators adopted the concepts independence of mind and independence in appearance. In October 2009, the General Standards on Professional Ethics (GSPE) was revised by the CICPA based on the IFAC Code of Ethics (2009) and used similar terms such as integrity, objectivity/independence, and professional competence and due care, confidentiality, and professional behaviour in the standard. The revised Code is named as CICPA Code of Ethics for Professional Accountants (CICPA CEPA) and was effective from 1 July 2010 according to the CICPA's announcement on its website (www.cicpa.org.cn). The CICPA Code of Ethics for Professional Accountants is very similar to the Australian APES110 Code of Ethics for Professional Accountants. There is no difference in terms of the basic structure and fundamental principles. For example, Part A of APES 110, General application for the code, is equivalent to 
the CICPA Code No.1- Fundamental principles of professional ethics. The ethical requirements in Part B of APES 110, Members in public practice, is similar to the CICPA's Code of Ethics for Certified Public Accountants, which includes five standards. Furthermore, Part C of APES 110, Members in business, is also similar to the CICPA's Code of ethics for non-practicing members.

\section{Audit independence of mind and in appearance}

As mentioned in the introduction, the first research question of the current study refers to how Australian and Chinese public accountants view the important independence issues in their code of professional ethics. Audit independence is deeply rooted in public accountants' professional conduct and is the cornerstone of the profession (Gill and Cosserat, 1996). Independence in mind is also closely associated with the virtues of objectivity, confidentiality and trust, core values of professional ethics. The accounting profession serves the public interest by increasing the accountability of its members, reinforcing trust and confidence in financial reports prepared by companies. Public accountants have obligations to review their clients' financial statements and ensure they properly reflect business performance. Thus public accountants are expected to bear in mind that they are required to act with integrity and exercise objectivity and professional skepticism.

Independence in appearance on the other hand represents public perceptions about the objectivity public accountants' activities and are unaffected by a financial interest in the assured client. This aspect of independence is more difficult to achieve in that it can be affected regardless of the accountant's mindset within a given decision making process. The relationships that accountants and auditors form with officers and other related parties associated with a client can create real and apparent concerns in the minds of various stakeholders. The existence of 
certain arrangements (real and/or imagined) can attract negative attention and include for example: the provision of non-audit services, lengthy client associations, and related management affiliations, matters affecting independence in appearance. During the assurance process auditors and their clients may intentionally or otherwise develop close interpersonal relationships and power dependence issues that influence the level of professional skepticism in practice (Lennox, 2005; Ye et al., 2011). The provision of non-audit services has been an issue of particular concern in the recent past in that it encourages auditors and their firms to foster close and personal relationships as a way of boosting profits (Craswell, 1999; Chung and Kallapur, 2003; Ye et al., 2011). As mentioned, auditors are in a position where as trusted agents they can leverage that position to gain advantage and build relationships that the public and regulators would view as affecting objectivity. Practitioners are therefore expected to avoid issues affecting independence in appearance. Thus Australian and Chinese public accountants in the current study are also expected to demonstrate strong views on the above independence issues.

Fan et al. (2012a) were the first to explore the application of a two-dimensional (7 item) instrument containing important independence issues for measuring Chinese auditors' perceptions of their code of professional ethics. The instrument was developed based on two latent constructs, namely independence of mind and independence in appearance. The former construct was measured using three items and the independence in appearance construct using four items. The results of an exploratory factor analysis (i.e., principle components analysis with Varimax rotation) showed the items are logically correlated and load onto identifiable factors. This two factor 7 item scale is shown in Table 1.

\section{Table 1: The code of professional ethics scale*}




\begin{tabular}{cll}
\hline Independence of mind & Independence in appearance \\
\hline 1. Be independent in performing an audit & 1. Avoid an employment offer from clients \\
2. Act with integrity and objectivity & 2. Avoid dependency from certain clients \\
3. Resist client's pressures to maintain independence & 3. Avoid a conflict of interest with clients \\
& 4. Avoid a close relationship with client
\end{tabular}

*Source: Fan et al., 2012a

The above constructs of audit independence are again applied in this current study. Independence in appearance has particular relevance when examined within an eastern cultural context where interpersonal connections in the form of guanxi are likely to play an important role in reinforcing business interactions, including audit-client relationships. Fan et al. (2012b) developed a two-dimensional instrument for measuring Chinese auditors' favour and rentseeking guanxi orientations that when applied in accounting practice has the potential of providing third parties with concerns that business professionalism (independence) may be threatened.

Fan et al. (2012b) distinguish clearly between two aspects of guanxi. The positive aspect, namely favour-seeking guanxi has similar attributes to the western concept of social networking theory and is commonly identified within business relationships. In a recent study of Australian and Chinese subjects (accountants and students), Fan et al. (2012c) report that survey respondents presented similar views about the relevance of such practices, which facilitate communications and contract achievement when all affected parties have equal access to information. Information asymmetry develops however, when the negative form of guanxi (rentseeking) is allowed to emerge, where the interests of some affected parties to a relationship are ignored (e.g., back-door deals, bureaucratic privilege etc.). In the last mentioned study, although survey respondents from both countries demonstrated some degree of concern about the rentseeking guanxi, Chinese respondents, as a group was more accepting of the notion, reflecting different underlying cultural predispositions. 
It is believed that the above concerns are again likely to be identified in this study of attitudes towards professional codes of ethics as they relate specifically to audit-client relationships (independence in appearance). However, at the same time, given that both Chinese and Australian accountants are subjected to very similar codes of practice; there is a prima facie expectation that both groups will be in agreement with respect to the importance of regulations requiring independence of mind. With these matters in view the following hypotheses are proposed:

$\mathrm{H}_{1}$ : Australian and Chinese public accountants will express similar views about the issues relating to independence of mind.

$\mathrm{H}_{2}$ : Australian public accountants are more concerned about the issues of independence in appearance compared to their Chinese counterparts.

\section{Code of professional ethics and ethical decision-making}

The second research question in this study concerns the relationship between public accountants' views about their code of ethics and their ethical perspectives. In the accounting and auditing literature, judgment and decision making research is based on behavioural decision theory, which is applied in this study in order to understand factors explaining how professionals make judgments and decisions in the workplace.

Many studies have examined whether the presence of a code of ethics affects the ethical decision making of business professionals. Findings are generally consistent; that is, the existence of a code of ethics improves ethical decision making across different professions. For example, Hunt and Vasquez's (1993) empirical study using Hunt and Vitell's (1986) general theory of business ethics provided support for the proposition that codes of conduct improve moral beliefs and decision making quality in business. McCabe et al. (1996) surveyed 160 
business personnel who graduated from two different colleges and found that graduates with strong code reinforcement experiences associated with lower levels of unethical behavior. Stohs and Brannick (1999) interviewed 348 Irish management directors from the private sector regarding their attitudes towards various questionable acts and results indicated that managers whose company has a code of ethics tend to rate unethical practices more seriously compared to those managers not subject to a code of ethics. Further, Somers (2001) conducted a survey on 613 American management accountants about their perceived concerns of unethical behaviours and their likely propensity to report observed activities. Their results also indicated that unethical behaviour is less prevalent in organizations that have a code of ethics compared to organizations that do not.

A study involving an accounting code of ethics was conducted by Herron and Gilbertson (2004). They investigated the influences of different forms of codes of ethics on 69 undergraduate accounting students' ethical judgments and intentions. Their findings indicated that subjects that have been provided with rules-based code of conduct are more likely to be sensitive towards independence issues, and to reject a questionable audit engagement. Pflugrath et al. (2007) investigated whether the presence of a code of ethics can improve auditors' judgment quality using samples of professional accountants and auditing students. The results showed that the presence of a code of professional ethics leads to higher quality of judgments of Australian accounting professionals but not on auditing students (proxies for future accountants). Further, Modarres and Rafiee (2011) investigated the ethical behaviour of 234 Iranian university students incorporated with the Iranian Association of Certified Public Accountants (IACPA) Codes of Ethics. Their findings indicated that familiarity with the Codes of Ethics for Professional Accountants leads to a greater appreciation of ethical issues and therefore a higher 
level of ethical judgment making. These examples tend to suggest a strong association between exposure to ethical codes of conduct and the moral judgments and intentions of accountants. In consideration of this association, this current study adopts the same approach as that applied by (Fan et al., 2012a), which focuses specifically on independence of mind and independence in appearance as they involve Chinese and Australian accounting professionals. In addition, given that modern accountants in both countries are exposed to very similar codes of professional conduct (as discussed earlier), the following hypotheses are presented:

$\mathrm{H}_{3}$ : The views Australian and Chinese public accountants have with respect to independence of mind issues are positively associated with their ethical judgments.

$\mathrm{H}_{4}$ : The views Australian and Chinese public accountants have about the concerns associated with independence in appearance are positively associated with their ethical judgments.

That is, it is proposed that codes of ethical conduct, such as those currently in use in both Australia and China, encourage accountants to take independence and client relationship issues seriously and that these attitudes positively influence the quality of their moral judgments. It is believed these relationships hold regardless of any cultural differences.

\section{Research method}

Sample selection and procedures of the data collection

A survey methodology was used in this study. The sampling units include practicing Chinese Australian public accountants. The instruments used for both groups include (a) a selfadministered questionnaire (refer to Appendix 1) and (b) a short auditing case involving an ethical dilemma (refer to Appendix 2). A Chinese expert (who speaks fluent English and Mandarin) was engaged to translate the scales from English to Chinese. Another Chinese expert 
then translated the scales back to English from Chinese to ensure equivalence in both languages. The sample selection and procedures of the data collection for each sample are as follows.

Chinese data: A sample of Chinese accountants was drawn from the Fan et al.'s (2012a) study. The Chinese sample includes mainly auditors employed in local accounting firms located in Shenzhen, Hangzhou, Beijing, and Kunming. The data collection was supported by the four Chinese accounting professional bodies i.e. (1) Shenzhen Institute of Certified Public Accountants; (2) Zhejian Institute of Certified Public Accountants; (3) Chinese Institute of Certified Public Accountants (CICPA); and (4) Yunnan Institute of Certified Public Accountants. Three hundred survey instruments were distributed in each of the four cities, culminating in a total of 1,200 potential respondents. The total number of responses received was 612 but 21 were excluded because they were incomplete. Thus 591 useable respondents were used in the study.

Australian data: A sample of public accountants employed in Western Australian accounting firms was used. An English version of the survey instrument was made available anonymously online. The method of recruitment was to make the survey link available to accountants and request their participation. A sample of 92 responses was collected through an online survey. Eleven of them were excluded from the research because they were incomplete due to inconsistencies and incompleteness leaving a final useable number of 81 respondents. The details of selected background information of respondents are shown in Table 2. Although the Chinese sample is much larger in number, the demographics are quite closely matched, the exception being that a large number of Australian professionals have completed postgraduate studies.

Table 2: Background information on respondents

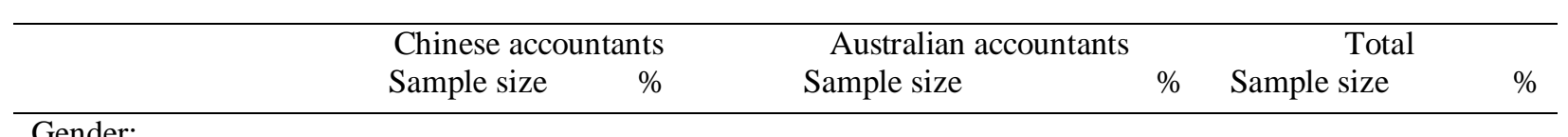

Gender: 


\begin{tabular}{lrrrrrr} 
Male & 257 & 50 & 41 & 51 & 516 & 86 \\
Female & 259 & 50 & 40 & 49 & 81 & 14 \\
$\quad$ Total & 516 & 100 & 81 & 100 & 597 & 100 \\
Education: & & & & & & \\
$\quad$ Undergraduate & 492 & 95 & 41 & 51 & 533 & 89 \\
Postgraduate & 24 & 5 & 40 & 49 & 64 & 11 \\
$\quad$ Total & 516 & 100 & 81 & 100 & 597 & 100 \\
Age: & & & 31 & 38 & 273 & 46 \\
$20-30$ & 242 & 47 & 38 & 47 & 238 & 40 \\
$21-40$ & 200 & 39 & 10 & 12 & 52 & 9 \\
$41-50$ & 42 & 8 & 2 & 3 & 34 & 5 \\
50 above & 32 & 6 & 81 & 100 & 597 & 100 \\
\hline Total & 516 & 100 & & & &
\end{tabular}

Measures

Measures of code of professional ethics: Fan et al.'s (2012a) two factor 7 items independence scale was used in this study and is to be applied in an equivalent manner using two independent country-based samples. There is in effect an expectation that respondents from each country will view the questions in the same fashion and therefore it is imperative that measurement invariance associated with the research instrument be considered. The measurement invariance issue is particularly relevant in cross-cultural studies where respondents speak different languages and use a translated version of a research instrument (Cheung and Rensvold, 2002). In this context, Horn (1991, p.119) also pointed out "without evidence of measurement invariance, the conclusions of a study must be weak". Thus it is important to ensure that the components of the instrument are viewed and understood in the same way by members of different cultures such as Australian and Chinese public accountants in the current study before a meaningful analysis can be made.

Joreskog's (1971) multi-group confirmation factor analysis (MGCFA) is recognized as the most powerful approach for testing instrument equivalence across groups (Steenkamp and Baumgartner, 1998). The prerequisite for testing the measurement invariance is to establish a baseline model for each group (Byrne, 1989; Vandenberg and Lance, 2000). Thus a confirmatory factor analysis using AMOS (Analysis of Moment Structures) is conducted to establish a 
baseline model separately for the Australian and Chinese samples. After the baseline models are identified, multi-group confirmation factor analysis (MGCFA) (Joreskog, 1971) is performed to ensure measurement invariance across groups is tested statistically as the baseline models in themselves do not "guarantee the equivalence of item measurements and underlying theoretical structure" (Byrne, 2010, p.205).

In testing measurement invariance of an instrument, it is believed that the tests of configural invariance and metric invariance are fundamental operations in the process of equivalence (Vandenberg and Lance, 2000; Du and Tang, 2005). Configural invariance tests whether compared groups have the same factor structure in relation to the underlying dimensions identified with respect to a common instrument while metric invariance tests whether the groups have the same factor loadings across the dimensions. Scalar invariance is another important issue to be considered in cross-cultural studies. It examines whether there is equality between the measure variable intercepts of the construct (Hair et al., 2010). This implies that the scalar test establishes whether two different groups use a response scale in a similar fashion (Hong et al. 2003; Campbell et al. 2008). Thus configural invariance, metric invariance, and scalar invariance were conducted to validate the instrument before compare the mean differences between Australian and Chinese public accountants.

For each group, a confirmatory analysis and model assessment is conducted separately until the most appropriate model is identified for further assessment. The model evaluations applied two popular methods, namely Chi-square $\left(X^{2}\right)$ statistic (i.e., $p \geq .05 ; X^{2} / \mathrm{df}<2$ ) and goodness-offit indexes (GFI) (i.e., TLI >.95; CFI >.95; RMSEA > .06) as suggested by $\mathrm{Hu}$ and Bentler (1999). After the baseline model, -or configural model is identified, metric invariance and scalar invariance are compared against to the configural model to determine the extent of any 
invariance. Fit indices (i.e. $\Delta \mathrm{CFI} \leq .01$ or $\Delta \mathrm{TLI} \leq .01$ ) (Cheung and Rensvold 2002) are commonly used criteria for the test of invariance and are applied in the current study.

The results of the confirmatory analysis for each group did not provide a satisfactory fit for the two-factor 7 item model (i.e., Australian group: $X^{2}=47.391, \mathrm{df}=13, p=.000$, TLI $=.80$, $\mathrm{CFI}=.88$, and RMSEA $=.18$; Chinese group: $X^{2}=113.986, \mathrm{df}=13, p=.000, \mathrm{TLI}=.92, \mathrm{CFI}=$ .95 , and RMSEA $=.123$ ). Thus the model re-specifications were undertaken for each group in order to determine one that better represents the same data. After reviewing the significant values of modification indices and standardised residual covariances (i.e., larger than 2) (Joreskog and Sorborn, 1989; Steenkamp and Baumgartner, 1998), the items, 'resist client's pressures to maintain independence', 'avoid an employment offer from clients', and 'avoid dependency from certain clients' represent likely misspecifications of the 7 item model. The confirmatory factor analysis was conducted again by deleting these three items one at the time until a satisfactory baseline model was identified.

The identified baseline model is shown in Figure 1 and the details of each subsequent model are shown in Table 3. Results suggest that the model represent the data perfectly (i.e., Chinese group: $\mathrm{p}=.67 ; \mathrm{TLI}=1.00 ; \mathrm{CI}=1.00 ;$ RMSEA $=.00$. Australian group: $\mathrm{p}=.58 ; \mathrm{TLI}=$ $1.00 ; \mathrm{CI}=1.00 ; \mathrm{RMSEA}=.00)$. It suggests that this two factor 4 item model is the confirmed baseline model for both Australian and Chinese groups. 


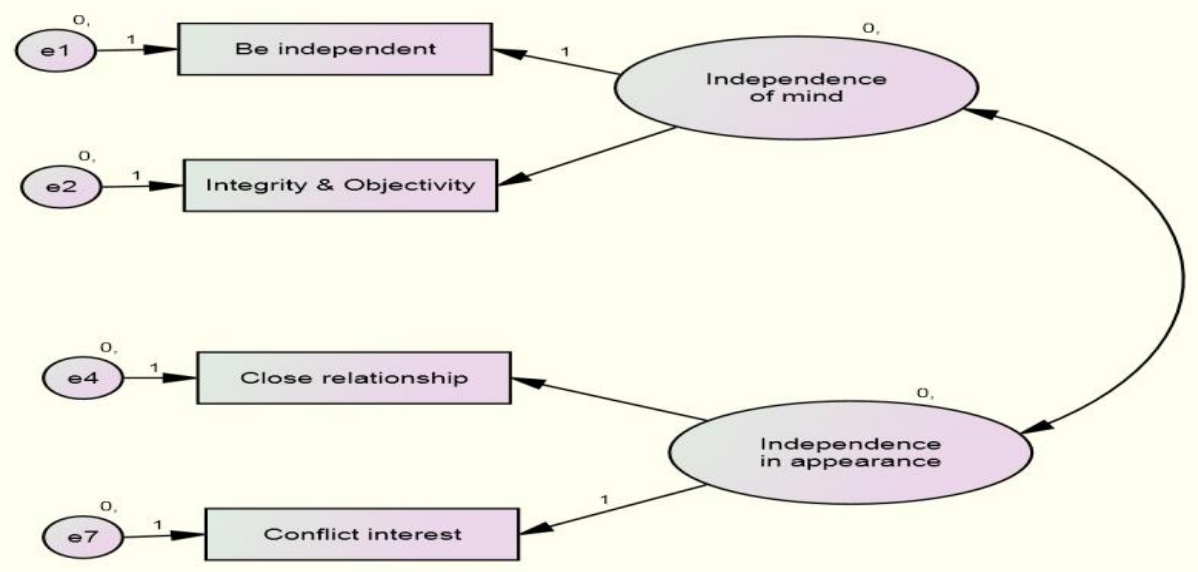

Figure 1: Two factor 4-item model of code of professional ethics

The results of multi-group confirmatory factor analysis (MGCFA) are also shown in Table 3. Results suggest that configural invariance (i.e., $p=.78, \mathrm{CFI}=1.00$, and RMSEA $=.00$ ) and metric invariance (i.e. $\Delta \mathrm{CFI}=0.01$ ) exist but that the scalar invariance (i.e., $\Delta \mathrm{CFI}=.04$ and $\Delta \mathrm{TLI}=.02)$ did not meet the criterion $\Delta \mathrm{CFI} \leq .01$ suggested by Cheung and Rensvold (2002). However, Little (1997) suggested that $\Delta \mathrm{TLI}$ less than or equal to $.05(\Delta \mathrm{TLI} \leq .05)$ also indicates a satisfactory model. Thus the scalar invariance is considered to exist by applying this criterion in the current study.

Table 3: Summary results of baseline models* and measurement invariance

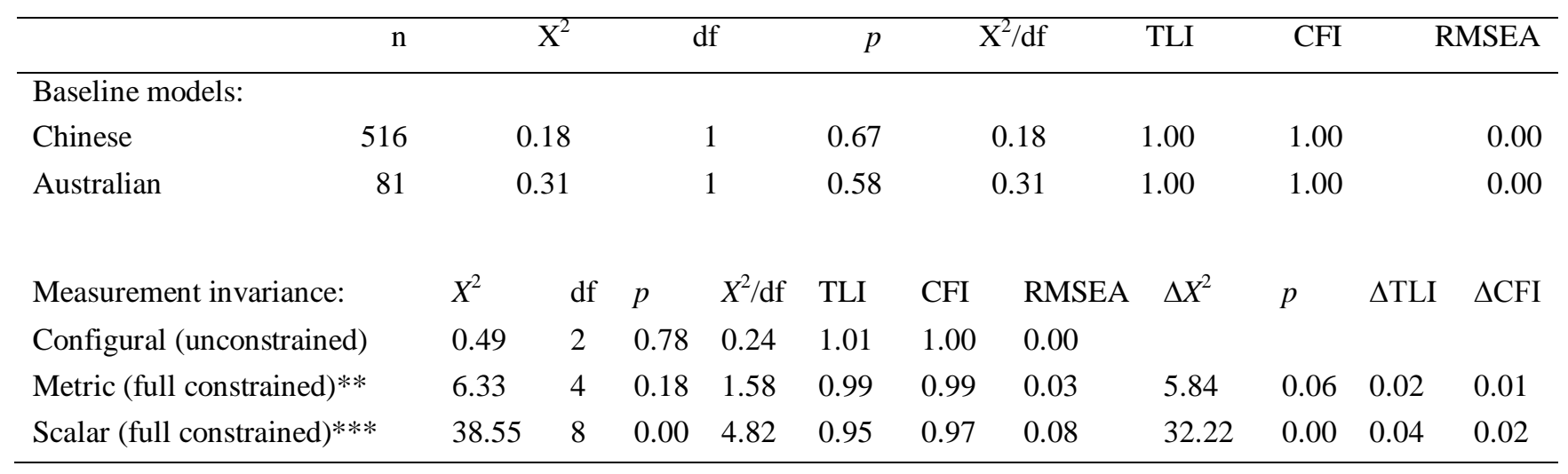


* A 2 factor with 4 items model; the factor 1, independence of mind, includes items: (1) be independent and (2) integrity and objectivity; the factor 2, independence in appearance, includes items: (1) conflict interest and (2) close relationship.

** assuming model unconstrained to be correct;

*** assuming model measurement weights (metric model) to be correct

Based on the above results, the views of Australian and Chinese public accountants on their code of professional ethics are measured using the baseline model. The coefficient of Cronbach's Alpha for the first factor, independence of mind, is 0.86 (Australian group 0.78; Chinese group 0.87) and for the second factor, independence in appearance is 0.76 (Australian group 0.76; Chinese group 0.71).

Measures of ethical judgment: The auditing ethical case included in the survey was acquired and modified from the American Accounting Association (1992) (see Roxas and Stoneback, 1997) and used to measure the ethical judgments of Australian public accountants and Chinese auditors (refer to Appendix 2). This case was chosen because it deals with a common ethical dilemma in auditing practice. Respondents are required to read the case and then answer two questions. The questions are concerned with an auditor's judgments about the ethical issues in two aspects: (1) external concerns - the bank and creditors may be deceived if an auditor makes the changes suggested by the client, and (2) internal concerns - an auditor's integrity will be compromised if he/she makes the changes suggested by the client. Respondents are asked to indicate their level of agreement with these two questions on a 7-point Likert scale. The scale ranged from strongly disagree (1) to strongly agree (7). The overall -reliability coefficient using Cronbach's Alpha for ethical judgment was 0.73 (Australian group 0.78; Chinese group 0.73).

\section{Results}

Results of respondents' views of code of professional ethics and their ethical judgments 
The mean score and standard deviation (SD) for each item of the code of professional ethics and ethical judgments are shown in Table 4. After applying one sample t-tests (applied to scale midpoint), the results show all items (i.e., four independence issues and two ethical judgments items) are higher than the mid-point (4) at $1 \%$ significance level. These results suggest that both Australian and Chinese public accountants are strongly supportive of their code of professional ethics. The act of independence (objectivity) is considered highly relevant and that they strongly agree to avoid close audit-client relationships.

\section{Table 4: Results of the Code and ethical judgments}

\begin{tabular}{|c|c|c|c|c|c|c|}
\hline & \multicolumn{2}{|c|}{$\begin{array}{c}\text { Chinese } \\
\text { accountants }\end{array}$} & \multicolumn{2}{|c|}{$\begin{array}{c}\text { Australian } \\
\text { accountants }\end{array}$} & \multicolumn{2}{|c|}{ Overall } \\
\hline & Mean & SD & Mean & SD & Mean & SD \\
\hline \multicolumn{7}{|l|}{ Independence of mind } \\
\hline 1. Be independent in performing an audit & 6.46 & .953 & 6.59 & .703 & 6.48 & .924 \\
\hline 2. Act with integrity and objectivity & 6.53 & .862 & 6.47 & .808 & 6.52 & .854 \\
\hline \multicolumn{7}{|l|}{ Independence in appearance } \\
\hline 1. Avoid a conflict of interest with clients & 5.84 & 1.353 & 6.46 & .852 & 5.92 & 1.313 \\
\hline 2. Avoid a close relationship with client & 5.81 & 1.340 & 6.30 & 1.259 & 5.87 & 1.339 \\
\hline \multicolumn{7}{|l|}{ Ethical judgments } \\
\hline 1. External concern for banks and creditors & 5.91 & 1.347 & 6.20 & .858 & 5.95 & 1.294 \\
\hline 2. Internal concern about CPA's integrity & 6.05 & 1.175 & 6.36 & .795 & 6.09 & 1.136 \\
\hline
\end{tabular}

Represents the grand mean for variables items along a seven-point scale $1=$ strongly disagree to $7=$ strongly agree

Independent samples t-tests were conducted to test the differences in views of code of professional ethics and ethical judgments between Australian and Chinese public accountants and the results are shown in Table 5.

Table 5: Results of independent samples t-test

\begin{tabular}{lllllll}
\hline & & & Sig. & Mean & Std. Error \\
F & Sig. & t & df & (2-tailed) & Difference & Difference \\
\hline
\end{tabular}




\begin{tabular}{llllllll}
\hline Independence of mind & 16.200 & .000 & -0.387 & 595 & .699 & -.039 & .100 \\
Independence in appearance & 12.368 & .000 & -3.945 & 595 & .000 & -.555 & .141 \\
Ethical judgments & 16.774 & .000 & -2.285 & 595 & .023 & -.294 & .129 \\
\hline
\end{tabular}

From the results of the t-tests, it is indicated that there is no significant difference between these two groups in terms of their views on the independence of mind factor ( $p$-value $=$ 0.699). On the basis of the arguments presented earlier, the findings support hypothesis $\left(\mathrm{H}_{1}\right)$, that Australian and Chinese accountants view issues relating to the importance of objectivity as somewhat equally important. However, Australian public accountants had significantly higher mean scores on the independence in appearance factor ( $p$-value $=0.000$ ) and ethical judgments $(\mathrm{p}$-value $=0.023)$ than their Chinese counterparts. These results suggest that Australian public accountants are more concerned about issues that create questionable audit-client relationships (including those associated rent-seeking guanxi) and that this is demonstrated by the significant differences in means. On this finding hypothesis $\left(\mathrm{H}_{2}\right)$, is supported.

In terms of ethical judgments relating to the auditing dilemma, Australian accountants recorded significantly higher mean scores than Chinese accountants at a 5\% significance level according to the results of the independence sample t-test.

\section{Results of the impact of the code of professional conduct on ethical judgment}

A linear regression was performed to examine whether independent variables, independence of mind and independence in appearance together act to predict the dependent variable, ethical judgment for Australian public accountants and Chinese auditors. The results of regression analyses are shown in Table 6.

Table 6: Regression results of the impact of Code on ethical judgments

\begin{tabular}{lllll}
\hline & Model & Std. Beta & t-Statistic & $p$-Value \\
\hline
\end{tabular}




\begin{tabular}{|c|c|c|c|c|}
\hline \multicolumn{5}{|l|}{ Overall } \\
\hline Independence of mind & - & .226 & 5.191 & .000 \\
\hline Independence in appearance & - & .091 & 2.097 & .036 \\
\hline$F$-value & 24.714 & - & - & - \\
\hline Significance & .000 & - & - & - \\
\hline$R^{2}$ & .077 & - & - & - \\
\hline \multicolumn{5}{|l|}{ Chinese group } \\
\hline Independence of mind & & .244 & 5.227 & .000 \\
\hline Independence in appearance & & .071 & 1.514 & .131 \\
\hline$F$-value & 22.016 & - & - & - \\
\hline Significance & .000 & - & - & - \\
\hline$R^{2}$ & .079 & - & - & - \\
\hline \multicolumn{5}{|l|}{ Australian group } \\
\hline Independence of mind & & .074 & .058 & .564 \\
\hline Independence in appearance & & .163 & 1.285 & .203 \\
\hline$F$-value & 1.793 & - & - & - \\
\hline Significance & 1.730 & - & - & - \\
\hline$R^{2}$ & .044 & - & - & - \\
\hline
\end{tabular}

The overall results provide a stable regression model $(\mathrm{F}=24.714 ; \mathrm{sig}=0.000)$ explaining almost $8 \%$ of the variance in the dependent variable ethical judgment. The independence of mind variable contributes most towards the explanation of changes in the dependent variable $(\mathrm{t}$-value $=$ $5.191, \mathrm{p}$-value $=0.000)$ and followed by independence in appearance $(\mathrm{t}$-value $=2.097, \mathrm{p}$-value $=$ 0.036). The positive beta coefficient values in both instances suggest respondents who support the principles that auditors must act independently and avoid close relationships with audit clients are more likely to be concerned about the inappropriateness of unethical business practices such as creative accounting in this case. That is, taken together, Chinese and Australian accountants who strongly align themselves with the requirements of their codes of ethical conduct are more likely to demonstrate greater moral concern for the issues associated with a typical auditing dilemma (i.e., score more highly in terms of their ethical judgment). Demographic variables, gender, education, and age, were included in the regression. However, none of them made any significant contribution in predicting the dependent variable.

The regression associated with the two national sub-groups (refer Table 6) provide further insight into the relationships between the variables at a national sub-level. The results 
show that neither independent variables are associated with Australian public accountants' ethical judgments (insignificant beta scores and p-values are listed for information). However, the results for the Chinese group provides a significant regression model $(\mathrm{F}=22.016$; $\operatorname{sig}=0$ .000) explaining $8 \%$ of the variance in the dependent variable, ethical judgment. One variable, independence of mind, is found to be positively associated with their ethical judgment making ( $\mathrm{t}$ value $=5.227 ;$ sig $=0.000)$, while the variable, independence in appearance is found not to be associated with their ethical judgment making.

Based on the above results, the hypotheses $3\left(\mathrm{H}_{3}\right)$ that the views of audit independence of Australian and Chinese public accountants are positively associated with their ethical judgments is supported based the overall results and is strongly supported in the Chinese group results. The hypotheses $4\left(\mathrm{H}_{4}\right)$, concerning independence in appearance finds some support when Australian and Chinese accountants are joined together but is not supported when analyzed within individual country groups.

\section{Discussion}

The first objective of this study was to examine the views about the code of professional ethics in the minds of Australian and Chinese public accountants. Constructs identifying independence of mind and independence in appearance were used to examine relevant aspects of their codes of professional ethics. A review of the current literature indicates that the codes applicable in both national systems are similar, but how they are understood and valued by accountants are matters worthy of investigation. When comparing beliefs and attitudes of groups of individuals in different settings it is important to ensure that the implements applied (e.g., questionnaires relating to issues of accounting independence) meet equivalence criteria. The instruments must 
be comprehended in the same way by each group. It was not sufficient to assume that the instruments are properly translated or culturally equivalent. It is also vital that they satisfy tests of invariance.

The authors of this paper responded to concern about measurement invariance by undertaking a refinement of the original seven item audit independence instrument developed by Fan et al. (2012a) using a sample of Australian public accountants. The methodology applied in this study confirms that such a concept can be explained by two factors based on the results of the confirmatory analysis resulting in a shorter four item version that results in a good fit of data.

. The tests suggest that regardless of cultural background all tested subjects establish that independence of mind can be accounted for by two variables (i.e., be independent in performing an audit, act with integrity and objectivity) and two variables (i.e., avoid a conflict of interest with clients, avoid a close relationship with client) associated with independence in appearance.

After applying the above two factor 4 item scale, the results suggest that both Australian and Chinese accountants demonstrate similar strong concerns about issues of audit independence of mind and in appearance but that the difference in means relating to the latter factor are significant. Australian public accountants appear significantly more concerned about the issues of independence in appearance than Chinese auditors, which may be due to the cultural differences. As discussed earlier, in Chinese society, interpersonal relationships have evolved to a point where they represent (as guanxi) a position of major significance within the milieu that defines its culture. Guanxi plays an important role in business relationships (Liu et al. 2011) and serves as one of the primary channels through which Chinese firms achieve their enterprise objectives. The findings of this study add support to the belief that interpersonal relationships are important and that Chinese auditors are aware of a connection between independence in 
appearance as represented in their national Code and their inherent understanding of guanxi. The relatively lower ratings of concern in relation to independence in appearance are consistent with the findings reported by Fan et al. (2012b) that Chinese auditors (the same respondents in the current study) relate highly to favour-seeking guanxi as part of business practice and that they accommodate to some extent its negative variant, rent-seeking guanxi. In contrast, many westerners view guanxi (especially rent-seeking guanxi) as unethical because it is often associated with corruption and bribery (Chan et al., 2002). The results of this study confirm a significant difference in views as they relate to the problems associated with independence in appearance. Chinese auditors are significantly less concerned about the moral implications associated with developing too close a relationship with clients. Their cultural perspectives relating to audit-client relationships clearly accommodate some degree of deviation from the spirit of the Code of professional ethics as it would be expected to apply in a western context.

The second objective of this study is to examine the impact of the views about the code of professional ethics of Australian and Chinese public accountants on their ethical judgments. Ethical judgment has been applied as a proxy for moral behaviour in practice and in the context of this study it acts more as a means of validating differences in ethical perspectives between national groups. A practitioner's level of concern about the ethicality of a business dilemma (refer to Appendix 2) should be expected to correlate to some extent with their understanding of the importance of related codes of ethics. The results of the current study are generally consistent with the findings reported in prior studies; attitudes towards codes of ethics act to predict ethical judgment. Independence of mind is the one element of the Code of ethics that appears to influence ethical judgment for Chinese accountants, but neither element influences the judgments of Australian accountants. 
Taken together, the attitudes of Chinese and Australian public accountants clearly indicate a significant and positive relationship between independence issues and moral judgment (refer Table 6). However, the variables together explain less than $8 \%$ of the variance in the dependent variable, suggesting that other untested factors deserve to be considered and evaluated. One concern the authors have regarding the outcome of this investigation of attitudes towards professional codes of ethical conduct is that although accountants respect these instruments as informing their moral duties, they do not necessarily relate closely with them. Knowing what is right and then doing it is something else. Without continuous sensitization and reinforcement of attitudes through training and development processes, attitudes can and do become lax and other self-serving considerations influence behaviour.

This study appears to be the first attempt to include aspects of an accounting code of ethics (viz., independence) into an ethical decision-making model, using samples of Australian and Chinese public accountants.. It also appears to be the first attempt to compare the views of Australian and Chinese members of professional bodies about aspects of their codes of professional ethics. Thus this study has some practical and theoretical significance. Firstly, it contributes to our understanding of the views of Australian and Chinese accountants on their code of professional ethics and the effects of these on their ethical judgments. This is particularly useful to the profession in that it will provide members with better insights into how accountants view the audit independence issues and their relationships with audit clients. Second, this study also offers a scale for measuring attitudes towards codes of professional ethics for further crosscultural studies.

The findings of this study must be considered in the light of the following limitations. Firstly, the comparative study examined two relatively disparate groups of accountants, a large 
sample of Chinese professionals employed mainly as auditors in local firms and a smaller Australian group of public accountants. The demographics may be similar although other cultural and business environmental factors are ignored, likely affecting the regression results. Secondly, a non-response bias exists in relation to the nature of the survey, which was voluntary and aimed at a less than random group of Australian accountants. Thirdly, the nature of the selfreport survey encourages participants to consciously or unconsciously exhibit a halo effect, providing responses that they believe serve to enhance preconceived ideas about what the survey is attempting to achieve. Finally, judgment was selected as a proxy for ethical decision making, which ignores a variety of other issues affecting behaviour, particularly motivation, moral intensity and moral character.

The results of this study provide some directions for further research. First, it could be worthwhile re-examining the relationship between Australian public accountants' attitudes toward their code of professional ethics and their ethical judgments in a large more representative sample. Second, it will be also worth re-examining the views of public accountants on their professional code in other countries using the instrument designed in this study. 


\section{Appendix 1: Code of Professional Ethics}

Do you regard it is reasonable to expect auditors:

1. to be independent in performing an audit?*

2. to act with integrity and objectivity in performing an audit?*

3 . to resist clients' pressures to maintain independence?

4. to avoid a close relationship with clients?*

5. to avoid an employment offer from a client?

6. to avoid dependency on fees from certain clients?

7. to avoid a conflict of interest with clients?*

(* Those items were used in the current study. Measured on a seven-point (7) response scale from Strongly disagree (1) to Strongly agree (7)).

\section{Appendix 2 Ethical judgment case}

CPA Chuck Adkins has just completed a year-end review and tax return for XYZ, Inc. XYZ is a five-year-old privately held company. During the five years, the business has grown substantially and has generated a comfortable living for its owner and CEO, Jack Hanson. In order to grow further, Hanson is considering taking the company public.

The company has failed, as many closely held businesses do, to keep careful records. Until now XYZ had not had an outside accountant. Consequently, most of the company's financial history is to be found in various loan applications and tax returns over the years. In anticipation of doing an audit when the company goes public, Adkins has been reviewing all of the past records that are available. Adkins review of the company's books has revealed various "soft spots" in the records as well as potentially undervalued assets.

In conversations with Adkins, Hanson has indicated that he plans to approach Big Bank for working capital to fuel expansion. The line of credit will be secured by all receivables, inventory, and equipment owned by the company. Hanson has been told that the line of credit has a formula related to fluctuating receivable and inventory levels and a fixed amount for the equipment.

The bank requires the review by an accountant as part of the loan approval process. After completing the review for the year just ended, Adkins calls Hanson and tells him that his company has suffered a significant loss of $\$ 125,000$. Sales during the prior three years had run between $\$ 1.5$ and $\$ 2$ million. Hanson responds that he had expected a loss like that because XYZ lost a major contract. Unless new business is found to replace the contract, things could be tight for a few years. 
After reviewing the financial statements with Adkins, Hanson tells him, "You know, if Big Bank sees these statements, we're sunk. We'll never get the line of credit." Adkins assures him that the company still has significant net worth despite a bad year. He doesn't think that Big Bank will reject the loan application over the one-year loss. Adkins suggests that Hanson go to the bank with a plan to deal with the problem, citing the five-year history of growth. Hanson is not convinced; the bank has made it clear that it would take a close look at current performance prior to extending the line of credit. If the credit isn't forthcoming, XYZ will have a hard time paying suppliers on time. If materials or parts are held up, delivery deadliness will not be met and the income situation will deteriorate further.

Hanson asks Adkins, "How can we make this look better? You accountants know that there are various ways to interpret and report data. Certainly you know how to change the numbers to present a better picture. Can't the undervalued assets be restated? What about all that goodwill we have generated by quality products and prompt service? That must be worth something. Or what about receivables? Maybe all those accounts that you wrote off weren't all that bad; perhaps we could carry some of them for a while longer. Tell me, what can we do now?"

Hanson's attitude makes Adkins uneasy. At the same time, XYZ is in an industry where Adkins's accounting firm has been trying to gain a foothold for some time. The XYZ account could mean as much as $25 \%$ of his firm's income in terms of all of the opportunities for service. In today's competitive market, every prospective client is valuable.

Please circle the answer that best describes your view to each statement.

1. I believe that the bank and the creditors may be deceived if Adkins makes the changes suggested by Jack Hanson.

$\begin{array}{lllllll}1 & 2 & 3 & 4 & 5 & 6 & 7\end{array}$

Strongly disagree $\quad$ Strongly agree

2. I believe that if Adkins makes the changes suggested by Jack Hanson his integrity will be impaired

$\begin{array}{rrrrrrrl}1 & 2 & 3 & 4 & 5 & 6 & 7 \\ \text { Strongly disagree } & & & & & & \text { Strongly agree }\end{array}$




\section{References:}

Bazerman, M. H., Morgan, K. P. and Loewwenstein, G. F. (1997), "The impossibility of auditor independence" MIT Sloan Mnagement Review, Vol. 38, Iss 4, pp.89-94.

Byrne, B. M. (1989), “A primer of LISREL: Basic applications and programming for confirmatory factor analytic model". New York: Springer-Verlag.

Byrne, B. M. (2010), "Structural equation modeling with AMOS basic concepts, applications, and programming". New York Routledge

Campbell, H. L., Barry, C. L., Joe, J. N. and Finney, S. J. (2008), "Configural, metric, and scalar invariance of the modified achivement goal questionnaire across African American and white university students", Educational and Psychological Measurement, Vol. 68, Iss 6, pp.988-1007.

Cezair, J. A. (2010), "How independent can an external auditor really be?" Internal Auditing, Vol 25, Iss2, pp.3-8.

Chan, R.Y.K., Cheng, L.T.W. and Szeto, R.W.E., (2002), "The dynamics of guanxi and ethics for Chinese executives", Journal of Business Ethics, Vol. 41, pp.327-336.

Cheung, G. W. and Rensvold, R. B. (2002), "Evaluating Goodness-of-Fit Indexes for Testing Measurement Invariance", Structural Equation Modeling Vol. 9, Iss 2, pp.223-55.

Chung, H. and Kallapur, S. (2003), "Client important, nonaudit services, and abnormal accruals" The Accounting Review, Vol. 78, Iss 4, pp.931-55.

Craswell, A. T. (1999), "Does the provision of non-audit services impair auditor independence?" International Journal of Accounting, Vol. 3, pp.29-40.

Du, L. and Tang, T. L. (2005), "Measurement invariance across gender and major: the love of money among university students in People's Republic of China", Journal of Business Ethics, Vol. 59, pp.281-93.

Fan, Y. H., Woodbine, G. and Scully, G. (2012a), “Chinese auditors' views about audit independence and their firms' ethical values", Asian Review of Accounting, Vol. 20, Iss1, pp.74-87.

Fan, Y. H., Woodbine, G. and Scully, G. (2012b), "Guanxi and its influence on the judgements of Chinese auditors", Asia Pacific Business Review Vol. 18, Iss 1, pp.83-97.

Fan, Y. H., Woodbine, G., Scully, G. and Taplin, R. (2012c), “Accounting students' perceptions of guanxi and their ethical judgments", Journal of Business Ethics Education, vol. 9.

Gill, G. S. and Cosserat, G. (1996), Modern auditing in Australia, Brisbane: John Wiley and Sons.

Hair, J. F., Black, W. C., Banin, B. J. and Anderson, R. E. (2010), "Multivariate data Analysis: A Global Perspective", New York: Pearson. 
Herron, T. L. and Gilbertson, D. L. (2004), "Ethical principles vs. ethical rules: the moderating effect of moral development on audit independence judgments" Business Ethics Quarterly, Vol. 14, Iss 3, pp.499-523.

Hong, S., Malik, M. L. and Lee, M. (2003), "Testing configural, metric, scalar, and latent mean invariance across genders in sociotropy and autonomy using a non-western sample”, Educational and Psychological Measurement, Vol 63, Iss4, pp.636-54.

Horn, J. L. (1991), "Comments on issues of mindorial invariance", in L. M. Collins and J. L. Horn (Eds.), Best Methods for the Analysis of Change, Washington, DC: American Psychological Association, pp. 117-44.

Hu, L. and Bentler, P. M. (1999), "Cutoff criteria for fit indexes in covariance structure analysis: Conventional criteria versus new alternatives" Structural Equation Modeling, Vol. 6, pp.1-55.

Hunt, S. D. and Vasquez-Parraga, A. Z. (1993), "Organisational Consequences, Marketing Ethics, and Salesforce Supervision”, Journal of Marketing Research February, pp.78-90.

Hunt, S. D. and Vitell, S. J. (1986), “A general theory of marketing ethics”, Journal of Macromarketing, Vol. 6, pp.5-16.

Jones, J., Massey, D. and Thorne, L. (2003), “Auditors' ethical reasoning: insights from past research and implications for the future", Journal of Accounting Literature, Vol. 22, pp.45-103.

Joreskog, K. G. (1971), "Simultaneous factor analysis is several popultations" Psychometrika, Vol. 36, Iss 4, pp.409-26.

Jöreskog, K. G. and Sörbom, D. (1989), “LISREL 7 user’s reference guide”, Chicago: Scientific Software.

Lennox, C. (2005), "Audit quality and executive officers; affiliations with CPA firms", Jounral of Accounting and Economics, Vol. 39, pp.201-31.

Little, T. D. (1997), "Mean and covariance structures (MACS) analyses of cross-cultural data: Practical and theoretical issues", Multivariate Behavioral Research, Vol. 32, pp.53-76.

Lui, G. and Ren, H. (2011), "A content analysis on the newly revised code of ethics for professional accountants in China”, in S. Susela Devi and K. Hopper (Eds.), Accounting in Asia (Research in Accounting in Emerging Economices), Emerald Group Publishing Limited, pp.35-60.

Lui, J., Wang, Y. and Wu, L. (2011), "The effect of guanxi on audit quality”, Journal of Business Ethics, Vol. 103, pp.621-38.

McCake, D. L., Trevino, L. K. and Butterfield, K. D. (1996), "The influence of collegiate and corporate codes of conduct on ethcis-related behavior in the workplace", Business Ethics Quarterly, Vol. 6, Iss 4, pp.461-76.

Modarres, K. and Rafiee, A. (2011), "Influencing factors on the ethical decision making of Iranian accountants", Social Responsiblelity Journal, Vol. 7, Iss1, pp.136-144.

Pflugrath, G., Martinov-Bennie, N. and Chen, L. (2007), “The impact of codes of ethics and experience on auditor judgments", Managerial Auditing Journal, Vol. 22, Iss6, pp.56689.

Roxas, M. L. and Stoneback, J. Y. (1997), “An investigation of the ethical decision-making process across varying cultures", The International Journal of Accounting, Vol. 32, Iss4, pp.503-35.

Sikka, P. (2009), "Financial crisis and the slilence of the auditors", Accounting, Organisations and Society, Vol. 34, Iss6-7, pp.868-73. 
Somers, M. (2001), "Ethical codes of conduct and organizational context: a study of the relationship netween codes of conduct, employee behavior and organizational values", Journal of Business Ethics, Vol. 30, Iss2, pp.185-95.

Steenkamp, J. E. M. and Baumgartner, H. (1998), Assessing measurement invariance in crossnational consumer research", Journal of Consumer Research, Vol.25, pp.78-90.

Stohs, J. H. and Brannick, T. (1999), "Codes and condcut: perdictors of Irish managers' ethical reasoning", Journal of Business Ethics, Vol. 22, Iss4, pp.311-326.

Vandenberg, R. J. and Lance, C. E. (2000), "A review and synthesis of the measurement invariance literature: suggestions, practices, and Recommendations for Organizational Research", Organizational Research Methods, Vol. 3, Iss1, pp.4-70.

Ye, P., Carson, E. and Simnett, R. (2011), "Threats to auditor independence: the impact of relationship and economic bonds", Auditing: A Journal of Practice and Theory, Vol. 20, Iss1, pp.121-48. 